\title{
温泉観光都市の計禹に関する考察 一城崎の場合一
}

(乥の1) 湿泉観光都市の都市部画上の站问题

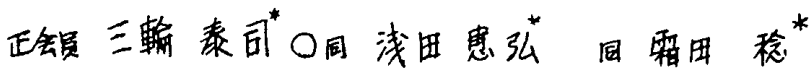

同尾上雅草”同乘岛光子“

1) 火山国であるわが国には温泉が多く、国民のレフリエーション生活と深く結でついている。温泉利用の

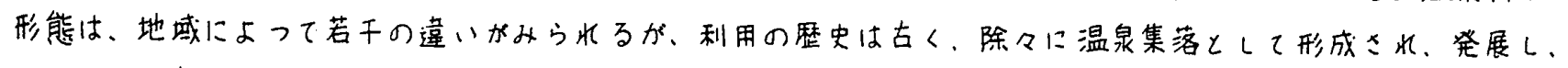
今日では温泉観光都市しよばれるまでになつてミた。㫕して、昔の湯治型利用の時代から、最近のレジメーによ

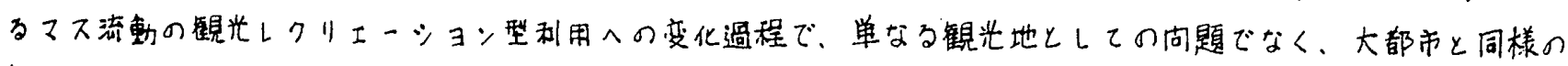

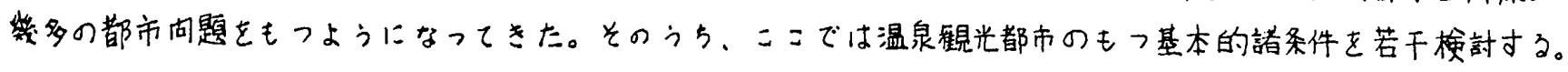

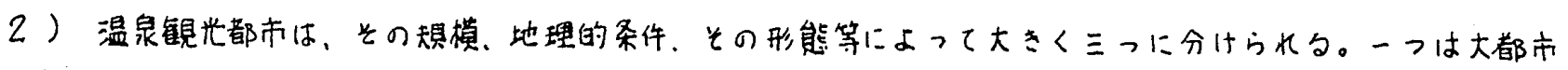
に比䡖的近い，交通上便利がよいとがいつた熱海白浜みどの都市化現象の強いものである。それ北対して、あま り都市化ミれていなく、曹かな自然に患ま北ているが，交通条件の恶い。あるいはへんぴな所に位置する温泉地

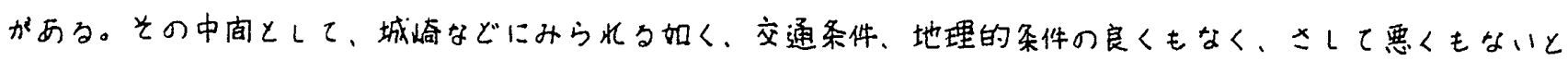
いつたところでかつかなり都市化が進んでいる温泉地があり、こ北が比較的多くをしめる。そ水らは、全国的に 知名性の高いもの、周西とが成束とかいつた広域圈内のもの、ヌは一地方にのかにとぶまっているもの等にお， さ゚つぱに补心する。知名性がより高くなり、钼光客の伸びが著しいほじ都市问題はきびしくなる。

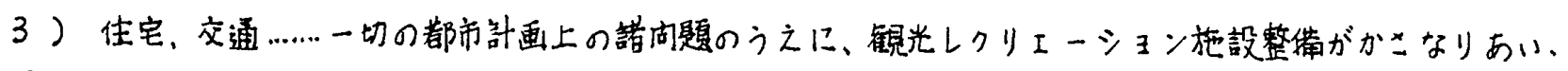

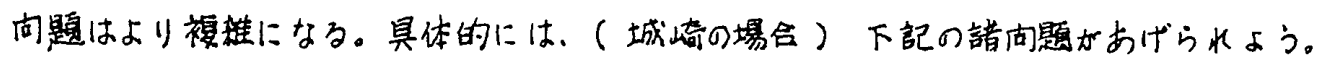

交通问題

保存修景

住宅古题

観光施設

公共施設

教育把設

厚生施設

広域上の南题

計画实行上の古題
通過交通をどうするが。(禁止，規制，)，バイハス建設。パーキンでの不足。

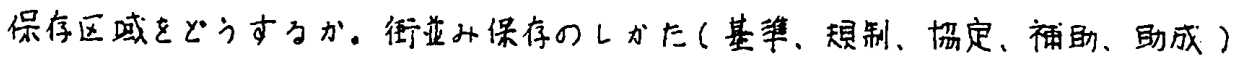
川、並木の美化をどうするか。

住宅需要、供給のウ法。建設埸所はどこか。

旅館の搪張はどうするが。外晹をどうするか。新しいレジー施設は必要か

役埸をどうするか、綿合宁舍とするか

小、中学の移設、䟢地利用、代替地、䨘用はどうするか

保育所、老人クラブ、診意所

踶光ルートの想定。

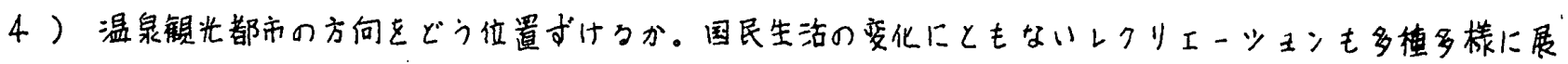
用していく。こ水カ放は、单にいまっでの温泉につかリ、温泉情粕架しむだけでは十分でなく、そこに何かで ラス新しい魅力を尊入する必要がある。温泉十古い魅力(温泉街らしニ、情緒)に加之て新しい魅力( 時代の



又。住民と共に考之る鼓画をつくリのげていくたのに次の方法をもちいる。

(1) 问题卓を具体的に住民が考亡うる程度にまでくだいて詂諸する。

(2) 町会誐真のみ+るらず地元育志が討諞に参加でミるような条件をつくる。

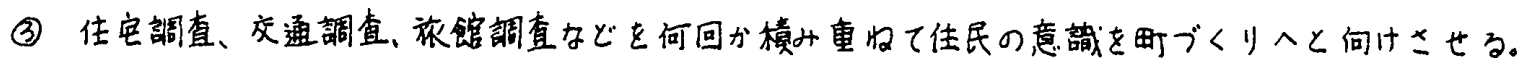

(4)自発的に生ま水た都市问題のたのの住民組織を組开込人でいく。 